\title{
PERANAN GURU PKn TERHADAP PEMBENTUKAN KARAKTER SISWA UNTUK MENINGKATKAN SIKAP NASIONALISME SISWA SMA NEGERI 1 PETIR KELAS XI IPS 2 KABUPATEN SERANG
}

\author{
E. Nita Prianti 1), Anton Aulawi ${ }^{2)}$,Siti Khadijah ${ }^{3)}$
}

Universitas Banten Jaya

Serang, Indonesia

nitaprianti18@gmail.com ${ }^{1)}$, anton.mutahari@gmail.com ${ }^{2)}$, sitikhadijah@unbaja.ac.id ${ }^{3)}$

\begin{abstract}
This research is aimed to investigate (1) role of Civics Education teachers in building students' character through nationalism attitude. The research results show that the teachers' role is highly needed because they are role models to make the students' behavior and character better and beneficial in terms of life, so that students of SMA 1 Petir can improve their character of nationalism. (2) factors which influence the building of nationalism character (3) the teachers' effort toward the students' character building. Based on the results of the research, in their way to solve the problem, the teachers use PAIKEM method, where the learning teaches active, innovative, creative, and fun learning. The research method used in this study is descriptive analysis research with a qualitative approach. The source of data in this qualitative research is gotten by digging information lexplanation directly from sources of information that are considered to be related to the building of students' characters in XI IPS 2 of SMA 1 Petir. As for the informants, this research gets Civics Education teachers and students of SMA 1 Petir. Data collection techniques used by the researchers in this research are interviews, observations, and documentation. In addition, the data analysis technics used by the researchers in this qualitative research are data reduction, display, and verification.
\end{abstract}

Keywords: The Role of Civics Education Teachers, Nationalism Character Building

\section{PENDAHULUAN}

Nasionalisme merupakan suatu paham yang mempertahankan kedaulatan suatu Negara, mempertahankan suatu konsep identitas bersama, untuk sekolompok manusia (Abdullah:2001). Nasionalisme dalam bangsa menujukan bahwa suatu bangsa mempunyai identitas jati diri yang tidak di miliki bangsa lain. Nasionalisme memiliki kesadaran bagi anak anak bangsa untuk membentuk bangsa yang merdeka. Harapan ini yang membentuk kesadaran masyarakat melawan bentuk segala penjajahan, penindasan. Nasionalisme merupakan bangsa dalam membentuk jiwa untuk mewujudkan jiwa patriolisme dalam mewujudkan karakter (Darma Kusuma:2013). Melihat dari kondisi semangat nasionalisme ini maka jiwa Nasionalisme harus di tanam kan sejak dini terutama pada generasi penerus bangsa serta kesadaran berbangsa bernegara. Pendidikan kewarganegaraan mengajarkan tentang sikap, perilaku, moral, yang dapat mempengaruhi dalam pembentukan karakter hidup manusia melalui pendidikan yang kemudian direalisasikan melalui proses pembelajaran di sekolah. Selain itu, mata pelajaran Pendidikan Kewarganegaraan (PKn) mempelajari 
tentang manusia selain sebagai makhluk individu yang mempunyai karakter khas masing-masing, sehingga berbeda dengan manusia yang lain. Selain sebagai makhluk individu mempelajari pula tentang manusia sebagai makhluk social, yang selalu berkelompok dan berinteraksi dengan manusia yang lainnya, dalam wadah keluarga, bangsa dan Negara. Melalui mata pelajaran Pendidikan Kewarganegaarn (PKn) peserta didik diarahkan untuk dapat menjadi warga Negara Indonesia yang demokratis, bertanggung jawab, berpartisipasi, serta warga dunia yang cinta damai. Selain itu dapat membangkitkan kesadaran siswa dalam hidup bermasyarakat, berbangsa dan bernegara, sehingga tumbuh adanya kesadaran dalam memiliki kebersamaan dalam kehidupan sosial. Jadi, pemahaman kesadaran Ilmu Pendidikan Kewarganegaraan merupakan titik awal dari timbulnya rasa memahami kehidupan bermasyarakat dan nilai-nilai sosial kemanusiaan, harga diri, kebersamaan, dan keterikatan (sense of solidarity), rasa keterpautan dan rasa memiliki (sense of belonging), kemudian rasa bangga (sense of pride) terhadap bangsa dan tanah air sendiri.

Dalam proses kegiatan pendidikan tentunya ada pihak yang harus bertanggung jawab di dalamnya. Penanggung jawab pendidikan di sekolah yang terlibat di dalamnya salah satuanya adalah para guru. Guru sangat berperan penting dalam dunia pendidikan yang merupakan pilar utama terhadap pengembangan manusia dan masyarakat suatu bangsa. Menurut (Kartono:1995) :mengemukakan bahwa "guru dituntut untuk menguasai bahan pelajaran yang akan diajarkan, dan memiliki tingkah laku yang tepat dalam mengajar." Oleh sebab itu guru harus dituntut untuk menguasai bahan pelajaran yang disajikan dan memiliki metode yang tepat pula dalam mengajar. dalam memberikan pengarahan, pengajaran, dan pendidikan (Tatang:2012). Oleh karena itu, peran guru sangat penting dalam membentuk perilaku siswa yang lebih bermoral. Seiring dengan kemajuan zaman maka semakin modern kehidupan manusia, semakin besar pula tantangan Nasionalisme yang harus dihadapi oleh manusia, di mana jarak bukan lagi halangan ditambah lagi media komunikasi telah menyatukan masyarakat menjadi Vilage Diasvora persebaran globalisasi yang pesat merupakan penyebab kemerosotan rasa Nasionalisme (Anur:2013). Sesuai fakta yang ada di lapangan, ketika diperhatikan bahwa peran Nasionalisme seolah bisa pudar, disamping siswa sering melanggar peraturan yang ada, kurangnya keperdulian siswa terhadap jasa para pahlawan yang telah berjuang melawan penjajah dengan segenap jiwa raga, kurangnya memaknai 
kegiatan upacara bendera, rendahnya motivasi diri dalam kegiatan belajar, kurangnya kecintaan terhadap tanah air sendiri serta kurangnya sikap kedisiplinan.

Dengan demikian, pentingnya sikap Nasonalisme melalui kesadaran diri demi terwujudnya cita-cita bangsa. Maka dari itu, peranan guru sangat penting dalam membentuk karakter sikap Nasionalisme baik terwujud dalam sikap, perilaku, maupun tindakan yang lainnya sesuai dengan harapan bangsa yang diinginkan.

Berdasarkan observasi yang di lakukan peneliti di kelas XI IPS 2 SMA Negeri 1 Petir khususnya pada mata pelajaran Pendidikan Kewarganegaraan (PKn) siswa kurang memperhatikan ketika guru sedang menjelaskan, kurangnya motivasi diri dalam belajar, Siswa tidak mengerjakan tugas yang di berikan oleh guru, kurangnya rasa ketertarikan siswa terhadap mata pelajaran Pkn dikarenakan dianggap membosankan sehingga minat perserta didik sangat kurang terhadap mata pelajaran tersebut.

\section{METODE PENELITIAN}

Dalam penelitian ini dilaksanakan pada siswa-siswi Kelas XI IPS 2 SMA Negeri 1 Petir. Adapun tempat penelitian ini di laksanakan pada bulan Maret 2018. Metode Penelitian ini adalah penelitian deskriptif dan pendekatan kualitatif. Teknik analisis data yang digunakan dalam penelitian ini adalah analisis data kualitatif, karena data yang sudah dikumpulkan dilakukan dengan analisa dan kemudian dipaparkan secara deskriftif (uraian), guna mendapatkan hasil dan kesimpulan. Data disebut kualitatif karena data yang diperoleh merupakan informasi naratif bukan berupa angka namun data tersebut adalah detail, terperinci dan jelas.

Sedangkan teknik pengumpulan datanya berupa observasi, wawancara, dokumentasi. Observasi, dimana penulis mengumpulkan data dengan melakukan penelitian langsung ke lokasi SMA Negeri 1 Petir. Wawancara, dalam penelitian ini peneliti mengajukan beberapa pertanyaan kepada guru dan siswa, bagi guru wawancara dilakukan untuk memperoleh data awal tentang pembentukan karakter siswa dalam meningkatkan sikap nasionalisme siswa, dan bagi siswa wawancara dilakukan untuk mengetahui seberapa besar pemahaman mengenai pembentukan karakter dalam meningkatkan sikap nasionalisme siswa. Wawancara ditanyakan secara langsung kepada guru dan siswa mengenai pembentukan karakter dalam meningkatkan sikap nasionalisme siswa, sedangkan data yang ingin di dapat dari hasil wawancara ialah mengenai pembentukan karakter dalam meningkatkan sikap nasionalisme siswa. Dokumentasi, dalam penelitian ini 
penulis mengumpulkan data melalui dokumen tertulis seperti arsip, buku-buku, hasil kerja serta pengambilan gambargambar yang berhubungan dengan masalah penelitian. sesuai yang di jelaskan. bahwa dokumentasi merupakan catatan peristiwa yang sudah berlalu. Dokumen bisa berbentuk tulisan gambar-gambar atau karya-karya (Sugiono : 2014).

\section{HASIL PENELITIAN DAN PEMBAHASAN}

\section{HASIL PENELITIAN}

Dari hasil penelitian yang telah dilakukan melalui Wawancara yang telah di laksanakan pada tanggal 14-30 April 2018 di SMA Negeri 1 Petir, maka data dan hasil yang di peroleh dari penelitian Peranan Guru PKn Terhadap Pembentukan Karakter Siswa Untuk Meningkatkan Sikap Nasionalisme Siswa SMA Negeri 1 Petir Kelas XI IPS 2 dapat dijelaskan sebgai berikut:

\section{Peranan Guru PKn Terhadap Pembentukan Karakter Sikap Nasionalisme Siswa di SMA Negeri 1 Petir}

Berdasarkan hasil penelitian yang telah diuraikan melalui pedoman wawancara dapat di gambarkan bahwa peranan atau cara guru PKn dalam membentuk karakter sikap Nasionalisme pada Siswa SMA Negeri 1 Petir adalah guru membentuk peribadi yang baik terhadap siswa dan siswa mampu merubah sikap perilaku dan disiplin waktu disamping itu, guru melibatkan peserta didik dalam kegiatan bela Negara. Seperti, menjadi petugas pengibaran bendera serta memberikan motivasi agar peserta didik mampu memberikan sikap dan perilaku yang menjunjung tinggi nilai kebinekaan. Siswa dalam proses pembalajaran berdasarkan hasil wawancara yang telah di laksanakan peneliti membuktikan bahwa pemahaman guru sanggat penting terhadap perubahan siswa mengenai sikap, perilaku, dan rasa cinta terhadap tanah air.

Berdasarkan hasil wawancara dapat di gambarkan bahwa peranan guru Pkn sangat penting dalam membentuk sikap Nasionalisme. Hal ini dibuktikan, siswa pada saat kegiatan ikut serta dalam perannya. Berdasarkan hasil wawancara pula, dapat dibuktikan bahwa siswa mampu menghadapi permasalahan yang dihadapi oleh peserta didik yang berbasis kurang perdulinya siswa terhadap sikap Nasionalisme selama ini. Disamping itu, guru perlu memberikan peringatan yang lebih tegas lagi agar siswa mampu menunjukan bahwa peserta didik bisa 
melakukan yang terbaik. Mampu dan sanggup mematuhi tata tertib sekolah dan disiplin waktu.

Berdasarkan penyataan di atas dapat disimpulkan bahwa pembentukan karakter sikap Nasionalisme yang di lakukan oleh guru Pkn pada siswa di SMA Negeri 1 Petir cukup berjalan dengan efektif karena guru membuat peraturan yang tegas apabila ada siswa/ siswi melanggar aturan tata tertib sekolah tersebut, akan diberi peringatan atau teguran terlebih dahulu, selanjutnya baru diberikan sangksi. Sehingga siswa tidak berani melakukan pelanggaran tersebut. Guru melakukan pembelajaran dan pembinaan dengan tujuan untuk membentuk karakter sikap Nasionalisme dengan cara melalui diantaranya ikut serta dalam kegiatan upacara bendera, ikut serta dalam kegiatan hari pahlawan serta ikut dalam suatu kegiatan yang mengatasnamakan pancasila (Kaelan : 2014).

Dengan demikian, maka guru sangat berperan penting di dalamnya dalam pembelaan Negara. Sehingga dengan adanya sikap Nasionalisme ini, siswa dapat memahami arti pentingnya sikap Nasionalisme. Sebuah ungkapan perasan cinta terhadap tanah air dan bangga menjadi bangsa Indonesia yang di inginkan.

Bangsa Indonesia, tampak pandang status senantiasa membela dan menjaga bangsanya dari ancaman dalam negara sendiri maupun dari Negara lain. Berdasakan hasil data yang di peroleh di SMA Negeri 1 Petir bahwa Sikap Nasionalisme merupakan suatu sikap yang mencitai tanah air yang menjaga kerukunan Negara kesatuan nya selalu mengedepankan kepentingan Negara didibandingkan kepentingan sendiri maupun kepentingan sekolompok orang, maka akan membangun karakter sikap Nasionalisme dan mau membangun tanah air menjadi lebih baik. Sikap Nasionalisme harus dimiliki oleh setiap siswa sebab dengan adanya cinta tanah air para pewaris bangsa dapat melindungi Negara dari ancaman dari bentuk apa pun sesuai dengan cita-cita terdahulu sikap Nasionalisme siswa. Baik di dalam sekolah maupun di luar sekolah harus di bentuk agar menjadi manusia berkarakter. Sehingga apa yang diharapkan yang harus di tanamkan siswa mampu menjadi generasi yang di harapkan bangsa dan Negara.

Sikap yang perlu dipertahankan oleh siswa adanya rasa hormat 
menghormati antara sesama. Dari hasil data yang di peroleh peneliti bahwa Sikap Nasonalisme siswa di SMA Negeri 1 Petir meliputi bangga sebagai bangsa Indonesia, cinta tanah air bangsa, rela berkorban demi bangsa dan Negara, menerima kemajemukan, bangga menjadi bangsa Indonesia dan menghargai jasa para pahlawan. Guru sebagai motivator ini erat kaitannya dengan pembentukan sikap Nasionalisme.

\section{Faktor Yang Menyebabkan Kurangnya Sikap Nasionalisme Siswa}

Dalam Pelaksanaan pembentukan karakter sikap Nasionalisme siswa guru memberikan penjelasan mengenai sikap Nasionalisme bahwa sangat penting dalam kehidupan berbangsa bernegara. Namun siswa tidak mengetahui pentingnya sikap Nasionalisme sehingga menjadikannya tidak peduli akan adanya rasa hormat menghormati sehingga kurang terjalin hubungan yang baik. Disamping itu, adanya factor lain yang mempengaruhi guru dalam membentuk karakter sikap Nasionalisme siswa. Berdasarkan hasil observasi yang peneliti lakukan selama ini, siswa belum mengetahui betapa pentingnya sikap Nasionalisme yang harus di jalankan oleh peserta didik.
Peranan guru sangat membantu karena dengan adanya guru siswa menjadi cerdas serta dapat membuat perubahan karakter dan sikap serta tingkah laku yang dapat menjadikan manusia yang berguna serta bermartabat. Berdasarkan hasil observasi dan wawancara guru PKn ini megatakan 'bahwa pembentukan sikap Nasionalisme ini berkaitan dengan pendidikan yang ada di dalam keluarga. Sikap anak yang manja membuat anak yang menjadikan sebuah alasan bahwa siswa yang tidak lagi memerlukan rasa Nasionalisme.

3. Upaya Guru PKn dalam Membentuk Karakter Sikap Nasionalisme Siswa

Untuk melaksanakan sebuah perubahan guna meningkatkan kualitas pendidikan bukanlah suatu perkara yang mudah untuk diwujudkan, akan tetapi membutuhkan sebuah proses melalui perjuangan dan pengorbanan dan adanya kerjasama antar berbagai pihak yang terlibat di dalamnya yaitu antara kepala sekolah dengan guru, guru dengan siswa, siswa dengan guru dan pihak-pihak lain yang terlibat di dalamnya.

Berdasarkan hasil penelitian, ada beberapa upaya guru PKn dalam membentuk karakter sikap Nasionalisme siswa yang harus 
ditempuh, yaitu melalui pembelajaran PKn dimulai dari antara lain: perencanaan, pelaksanaan, evaluasi dan kegiatan upacara serta mempunyai rasa bangga terhadap sikap Nasionalisme

\section{a. Perencanaan}

Perencanan pembelajaran mulai dari penyusunan program tahunan, program semester, Silabus dan RPP khususnya. Indikator di susun berdasarkan standar kompetesi dan kompentesi dasar, sebagaimana dicantumkan lampiran Pendidikan Nasional No. 22 Tahun 2006 tentang standar isi untuk satuan pendidikan dasar dan menengah.

Berdasarkan hasil wawancara, observasi dan pengamatan serta studi dokumentasi yang dilakukan peneliti mulai april 2018 dapat diketahui bahwa persiapan pembelajaran yang dilakukan oleh guru mata pelajaran Pkn di SMA Negeri 1 Petir dianggap efektif dalam mengajar. Berdasarkan hasil penelitian dapat memberikan gambaran ketika guru mengajar adanya persiapan melalui adanya SILABUS, RPP yang sudah tersedia.
Pembelajaran berdasarkan kompetensi, dasar materi, pembelajaran nilai budaya dan karakter bangsa ,dan alat pembelajaran. Penyusunan silabus ini dikerjakan bersama sama guru Pkn di SMA Negeri 1 Petir hingga terjalin komunikasi antar guru. Selain itu dapat memberikan arahan apabila menghadapi permasalahan pembuatan Silabus dan RPP. Wakil Kepala Sekolah juga mengarahkan kepada guru Pkn mengenai kebijakan pendidikan.

Karakter sikap Nasionalisme yang dicantumkan dalan silabus, yang berarti tahap pembelajaran persiapan guru Pkn dalam proses penanaman sikap Nasionalisme sudah diterapkan dalam pembentukan karakter sikap Nasionalisme siswa oleh Guru PKn.

\section{b. Pelaksanaan}

Pembentukan sikap Nasionalisme tiap siswa berbeda-beda tergantung pemahaman tentang Nasionalisme maupun di lingkungan keluarga dan teman sebaya yang turut berpengaruh pada sikap seorang pada proses pembentukan sikap nasionalisme 
ini melalui pembelajaran $\mathrm{Pkn}$ yang menjelaskan kepahlawanan. Pelaksanaan pembentukan sikap Nasionalsme tidak langsung terbentuk dalam diri siswa secara instan namun membutuhkan proses. Sikap Nasionalisme ini diharapkan menjadi bekal dalam kehidupan berbangsa dan bernegara sesuai dengan Pancasila. Pengamatan dilakukan mulai dari sarana dan prasarana yang menunjang dalam pembentukan sikap Nasionalisme serta sikap atau tingkah laku siswa ketika berada di dalam sekolah. Selain itu peneliti mengamati "Peranan Guru Pkn dalam Membentuk Karakter Sikap Nasionalisme" dilakukan dari berbagai proses di antaranya dalam pembelajaran melalui pengamatan yang sudah di lakukan oleh peneliti. Pelaksanaan guru Pkn dalam membentuk karakter sikap Nasionalsme. Berdasarkan hasil pengamatan melalui materi Pembelajaran. Pembelajaran PKn dapat dilaksanakan dengan baik di dalam maupun di luar kelas masing-masing. Guru PKn memilikI keahlian dalam menyampaikan

materi

pembelajaran. Penyampaian materi oleh guru tentang sikap Nasionalisme memerlukan pengetahuan yang mendalam bagi $\begin{array}{lll}\text { guru } & \text { PKn dalam }\end{array}$ melaksanakannya, gurulah yang memberikan pemahaman bagi siswa tentang arti Nasionalisme. "Menurut Bapak Seluri M.Pd selaku guru Pkn kelas X1 IPS Mengatakan: “ Peranan bapak dalam membentuk sikap Nasionalisme ini adalah dengan cara ikut serta dalam upacara setiap hari senin".Banyak cara dalam pembentukan sikap Nasionalisme ini perlu diperhatikan oleh siswa antara lain: Selalu tepat waktu dalam melaksanakan upacara, tidak telat atau pun kesiangan. Tentunya penerapan dimulai harus dari guru terlebih dahulu dalam membentuk karakter sikap Nasonalisme. Belajar dengan semangat kebangasaan, rasa ingin tahu, dalam materi pembelajaran, cara ini dilakukan agar siswa selalu semangat dengan adanya pembelajaran PKn ini menjadikan siswa agar bersungguh-sungguh dalam pembentukan semangat 
kebangsaan. Yang dilakukan guru untuk meningkatkan minat siswa terhadap mata pelalajaran PKn.

\section{c. Evaluasi}

Evaluasi dijelaskan sebagai penilaian, proses pengukuran terhadap kemampuan siswa dalam kegiatan proses pembelajaran meliputi pengetahuan, sikap, dan keterampilan untuk membuat keputusan mengenai kemampuan siswa (Ratnawulan \& Rusdiana : 2015). Tujuan evaluasi ditekankan pada penguasaan sikap afektif dan psikomotorik untuk mengetahui pengetahui kemampuan siswa. Selain itu sesuai yang dijelaskan oleh (Zainal Arifin:2016) evaluasi dipergunakan untuk menghimpun informasi yang dijadikan dasar untuk mengetahui taraf kemajuan, perkembangan dan pencapaian belajar siswa serta keefektifan pengajaran guru. Berdasarkan data yang didapat dari hasil penelitian. Peneliti mengambil data melalui dokumentasi tertulis seperti Arsip, dan buku raport. Hasil yang didapat oleh peneliti membuktikan bahwa penilaian terkait pembentukan karakter siswa di sekolah SMA Negeri 1
Petir Kelas XI IPS 2 menandakan cukup baik.

\section{d. Upacara Bendera}

1. Upacara Bendera Setiap Hari Senin Di sekolah SMA Negeri 1 Petir selalu mengadakan upacara setiap hari senin upacara bendera merupakan kegiatan untuk membentuk karakter sikap Nasionalisme siswa di laksanakan dengan cara agar siswa mengarhai jasa para pahlawan yang telah gugur memperjuangkan kemerdekan. Kegiatan upacara tujuanya agar siswa SMA Negeri 1 Petir membangun kembali jiwa Nasionalisme. Sekolah memberikan hukuman kepada siswa yang tidak mengikuti kegiatan upacara bendera karena terlambat dengan hukuman hormat bendera dan menyanyikan lagu Indonesia raya hal ini di maksudkan agar siswa tidak terlambat dalam melaksanakan kegiatan upacara bendera dan mampu menghargai jasa para pahlawan

2. Upacara Bendera Peringatan Hari Besar Nasional dan Bertema Nasionalisme

Setiap tahun sekolah SMA Negeri 1 Petir mengadakan peringatan hari besar Nasional. sekolah 
mengadakan upacara bendera dan serangkaian perlombaan yang bertema kan 'Nasionalisme siswa yang terlambat hadir atau tidak mengikuti upacara diberi hukuman hormat bendera sambil menyanyikan lagu Indonesia raya di berikan kepada siswa karena merangsang untuk memberikan efek jera agar siswa tidak mengulangi lagi dikemudian harinya hal tersebut sesuai dengan konsep pembinaan hukuman (Hasbullah:2005) sebagai tindakan hukuman atau sanksi diberikan karena melakukan pelanggaran agar tidak terulang pelanggaran kembali. Perlombaan yang di laksanakan di sesuaikan dengan kegiatan hari besar nasional mengiukan seruruh warga sekolah, mulai dari siswa, guru kariawan, SMA Negeri 1 Petir kegiatan hari besar nasional di laksanakan kegiatan pembentukan jiwa Nasionalisme pada kalangan siswasiswi dengan berbagai kegiatan perlombaan.

3. Memasang Atribut di Dalam Kelas Salah satu upaya membangun jiwa Nasionalisme pada siswa-siswi SMA Negeri 1 Petir atribut-atribut, bendera merah putih, gambar presiden dan wakil presiden, gambar Garuda Pancasila di pasang setiap ruangan kelas dengan tujan agar siswa mampu membentuk karakter sikap Nasionalisme yang baik, mampu meningkatkan sikap Nasionalisme dengan berbagai peranan yang dilakukan guru PKn dalam membentuk karakter sikap Nasionalisme pada siswa.

Hal ini terlihat saat observasi proses pembelajaran PKn di kelas XI IPS 2 guru selalu berusaha memberikan pertanyaan terkait materi yang diajarkan agar siswanya benar-benar memahami pembelajaran pembiasaan yang dilakukan guru PKn melalui kegiatan upacara bendera. Guru memperingkatkan pada siswa agar aktif melalui kegiatan tersebut, guru sangat berharap peserta didiknya mampu berinteraksi di dalam kegiatan peringatan serta dapat mampu memberikan peran serta dalam perannya dikarenakan siswa sangat sulit untuk membentuk karakter sikap yang sesuai dengan kenyataan yang ada. Pada saat ini guru sangat berperan serta dalam membentuk karakter sikap Nasionalisme, mengingat kenyataan yang ada di lapangan siswa tidak begitu menyukai dengan pembelajaran PKn karena dianggap sangat membosankan sehingga timbul rasa 
malas pada saat pembelajaran berlangsung. Siswa tidak memperhatikan pelajaran melainkan ngobrol sehingga pembelajaran tidak efektif. Peranan guru ini sangat dibutuhkan agar proses belajar menjadi lebih efektif, sehingga siswa tertarik ingin mempelajari mata pelajaran PKn. Berdasarkan hasil wawancara seperti yang di ungkapkan oleh Faiz Kelas XI IPS 2 sebagai berikut : 'Nasionalisme adalah menghormati bangsa Indonesia dan harus ada pada diri masing-masing pada diri bangsa agar mereka tau bangsa Indonesia memperjuankan (wawancara: Muhamad Faiz siswa Kelas XI IPS2 SMA Negeri 1 Petir. Peranan ini sanggat di butukan kan peran siswa ini sangat di butukan agar siswa siswi menjadi tertarik dalam melaksanakan serta mampu untuk perubahan sikap perilaku yang sesuai dengan harapan. Dari hasil data yang diperoleh peneliti bahwa sikap Nasionalisme siswa di SMA Negeri 1 Petir memiliki rasa bangga menjadi bangsa Indonesia, cinta tanah air, rela berkorban. Selain beberapa point diatas berdasarkan hasil wawancara dapat di gambarkan bahwa upaya upaya guru terhadap pembentukan karakter siswa dengan memberikan motivasi dan dorongan pada siswa yaitu dengan cara memberikan bimbingan dan contoh-contoh potopoto pahlawan serta pelaksanaan Upacaranya sehingga dapat menjadi motivasi bagi kalangan pelajar agar bisa menjadi lebih baik lagi . Berdasarkan hasil wawancara dapat di gambarkan dengan melalui metode yang di terapkan Guru PKn kepada siswa SMA Negeri 1 Petir dengan cara memberitahukan saat pelaksanaan Upacara guru PKn membuat sebuah kegiatan seperti cerdas cermat serta kegiatan lainnya yang harus kita pertahankan dalam rangka membentuk karakter sikap Nasionalisme . siswa harus ikut serta dalam pembentukan karakter sikap nasionalisme siswa sehingga menjadikan pesrta didik mampu untuk perubahan sikap perilaku yang mencerminkan peran guru PKn dalam merubah perilaku siswa yang tadinya kurang baik harus lebih baik lagi serta adanya saling menghargai antara siswa dan dalam pembelajaran pendidikan kewarganegaran. Upaya lain adalah dengan menggunakan metode yaitu guru PKn dalam membentuk karakter sikap Nasionalisme siswa di SMA Negeri 1 Petir. Berdasarkan wawancara yang dilakukan peneliti pada saat di lapangan pembelajara 
guru PKn mengunakan strategi/metode "PAIKEM" pembelajaran ini, guru mampu menciptakan suasana yang menyenangkan agar siswa bisa aktif dalam kegiatan pembelajaran, mampu untuk membangun pengetahuan siswa terhadap suatu gagasan baru, serta menciptakan suasana yang menyenangkan serta guru harus mampu serta tepat dalam mendidik agar siswa mau menerima pembelajaran yang menyenangkan sehingga siswa dapat memahami serta ingin mempelajari PKn. Namun pada kenyatan siswa tidak menyukai pembelajaran pendidikan kewarganegaran yang di angap sulit peran guru dalam pembelajaran ini harus lebih cerdas serta mampu membangkitkan semangat jiwa Nasionalisme siswa. Peranan guru pendidikan kewarganegaran ini sangat penting dalam membentuk perilaku serta mampu menubuhkan jiwa kebangsaan, namun pada kenyatan siswa tidak melakukan serta kurang peduli nya siswa dalam pembelajaran serta peranan guru dalam membentuk srategi yang menyenang kan seperti hal yang dilakukan serta kewajiban pelajar dalam membina serta membentuk. Karakter yang sesuai dalam peraturan serta adanya saling menghargai peran guru ini sangat menentukan karakter serta sikap, perilaku yang tidak sesuai dengan pembentukan yang di harapkan. Sehingga kedepan siswa siswi SMA Negeri 1 Petir menjadi manusia yang berguna bagi diri nya ,masyarakat umumnya bagi masyarakat. Metode ini merupakan metode yang digunakan guru PKn dalam pembelajaran aktif, inovatif, kreatif, epektif, dan menyenangkan agar siswa dapat mengerti materi yang diajarkan guru sehingga apa yang di harapkan terwujud. Peranan guru ini sangat dibutukan agar siswa mampu dan menjadi pigur yang baik sehingga siswa tersebut menjadi kebanggaan. Pembelajaran PKn yang di intergrasikan dengan pembentukan karakter sikakap ada bagian ini akan di sajikan hasil penelitian di lapangan yang meliputi Peranan Guru PKn terhadap pembetukan karakter sikap Nasionalisme siswa untuk meningkatkan sikap Nasionalisme siswa.

\section{SIMPULAN}

Berdasarkan pembahasan dan hasil penelitian yang telah dilaksanakan oleh peneliti di sekolah SMA Negeri 1 Petir dengan judul "Peranan Guru PKn Terhadap Pembentukan Karakter Siswa 
Untuk Meningkatkan Sikap

Nasionalisme Siswa SMA Negeri 1

Petir Kelas XI IPS 2 Kabupaten Serang.

Dapat disimpulkan sebagai berikut:

1. Peranan Guru PKn dalam membentuk karakter sikap Nasionalisme siswa dengan cara membentuk karakter sikap Nasionalisme seperti halnya kegiatan peringatan hari pahlawan, upacara bendera setiap hari senin dan peran guru sangat di butuhkan dalam pembentukan karakter siswa.

2. Upaya yang di lakukan guru PKn dalam membentuk karakter sikap Nasionalisme di antaranya adalah melalui perencanaan pembelajaran, pelaksanaan pembelajaran, melakukan evaluasi, cerdas cermat dalam kegiatan debat sehingga siswa dapat termotivasi, pemberian arahan mengenai pentingnya sikap Nasionalisme.

3. Proses pembentukan sikap Nasionalisme dilakukan Guru PKn dalam membentuk karakter sikap Nasionalsme baik di lingkungan sekolah maupun di luar sekolah.

4. Hambatan-hambatan guru PKn dalam membentuk karakter sikap Nasionalisme yaitu siswa yang kurang memahami arti cinta terhadap tanah air serta kurang ketertarikan siswa terhadap mata pelajaran PKn karena di anggap kurang menarik dan membosankan. Disamping itu, kurangnya kepedulian siswa terhadap sikap dan perilaku yang tidak sesuai dengan Pancasila. Sehingga merosotnya sikap Nasionalisme di kalangan generasi saat ini. Maka dari itu, perlunya guru PKn dalam membentuk karakter sikap Nasionalisme di SMA Negeri 1 Petir dengan cara ikut serta dalam peringatan hari pahlawan, melakukan upacara bendera pada hari tertentu sehingga peranan guru sangat di harapkan.

5. Upaya guru PKn dalam membentuk karakter sikap Nasionalisme mengalami hambatan-hambatan, antara lain kurangnya siswa dalam memahami arti pentingnya sikap Nasionalisme. Selain itu, Masalah yang harus dihadapi guru PKn dalam membentuk karakter siswa, guru harus selalu berusaha membentuk karakter sikap Nasionalilime agar siswa dapat menunjukan kesungguhan dalam setiap langkah agar di masa yang akan datang apa yang di inginkan oleh guru dapat mudah tercapai sesuai yang diharapkan. 


\section{DAFTAR PUSTAKA}

Abdulah, Tariff. 2001. Nasionalisme

Sejarah. Bandung: Sahaya Historika.

Anur, Hari. 2013. Pembudaya

Nasionalisme. Junal ilmah Pkn

Arifin, Zainal. 2016. Evaluasi

Pembelajaran. Bandung: Remaja

Rosdakarya.

Depdiknas, 2006. Permen Nomor 22 Tahun

2006. Jakarta : Depdiknas.

Dharma, Kesuma dkk. 2013. Pendidikan

Karakter. Bandung: PT. Remaja

Hasbullah. 2005. Dasar-dasar Ilmu

Pendidikan (edisirevisi). Jakarta: PT.

Raja Grafindo Persada

M.S, Kaelan. 2014. Pendidikan Pancasila.

Yogyakarta: Paradigma

PP.RI. No.74. Tentang Guru. Bandung:

Citra Umbara.

Ratnawulan, E \& Rusdiana. 2015. Evaluasi

Pembelajaran. Bandung: CV. Pustaka

Setia.

Sugiyono. 2014. Metode Penelitian

Kuantitatif dan Kualitatif. Bandung:

Alfa Beta

Tatang, S. 2012. Ilmu Pendidikan.

Bandung: Pustaka Setia.

UU. No.14.2005. Tentang Guru dan Dosen.

Bandung: Citra Umbara 